IV - 1 | 2012

Pragmatism and the Social Sciences: A Century of Influences and Interactions, vol. 2

\title{
Between Science and Fiction
}

Pragmatism and Conservatism in History and Law

\section{Seth Vannatta}

\section{(2) OpenEdition}

\section{Journals}

Electronic version

URL: http://journals.openedition.org/ejpap/779

DOI: 10.4000/ejpap.779

ISSN: 2036-4091

\section{Publisher}

Associazione Pragma

Electronic reference

Seth Vannatta, «Between Science and Fiction », European Journal of Pragmatism and American Philosophy [Online], IV - 1 | 2012, Online since 23 July 2012, connection on 02 May 2019. URL : http:// journals.openedition.org/ejpap/779 ; DOI : 10.4000/ejpap.779

This text was automatically generated on 2 May 2019.

\section{c) (†) $९$}

Author retains copyright and grants the European Journal of Pragmatism and American Philosophy right of first publication with the work simultaneously licensed under a Creative Commons AttributionNonCommercial-NoDerivatives 4.0 International License. 


\title{
Between Science and Fiction
}

Pragmatism and Conservatism in History and Law

\author{
Seth Vannatta
}

\section{Introduction}

1 Of particular interest to the relationship between pragmatism and the social science of history is the parallel relationship of the social sciences to the humanities. History departments do not have a singular vision of where their discipline lies upon the long spectrum of methods and self-images from the "soft" narrative and story-telling to the "hard" scientific study of history. Even within departments there are debates about whether history should count as a social science distribution requirement or a humanities distribution requirement. Therefore, we need to look at some conceptual options for how to think about historical inquiry. That is, presenting a genesis of the conceptual options will give us a lay of the land, enabling us to see the particular contributions of classical American pragmatism to the method of historical inquiry.

Between Martin Heidegger signaling the end of metaphysics (Heidegger 1927) and JeanFrançois Lyotard characterizing our postmodern condition, (Lyotard 1979) the social sciences faced a crisis. Historicists of a postmodern hue, including but not limited to Lyotard, responded to the Marxist Hegelian conception of history as a continuous series of well-defined social worlds and showed that universalized philosophies of history were in fact contingent products of socialization and cultural circumstance. This critical theme registered as a rejection of any foundational meta-narrative structure meant to maintain continuity throughout history. The American neo-pragmstist Richard Rorty registered an attack on any philosophy attempting to mirror nature or cut it "at the joints," by positing an incognizable substructure - from "God" to "substance," "matter," "energy," and "atoms" - to secure its continuity and observability (Rorty 1985: 3).

With philosophy qua metaphysics toppled, with all of its meta-narratives undermined, on what ground could the social scientist stand to investigate human relations, social worlds, and institutions? Worse still, how could historians understand the transformation of the 
same over time? Those engaged in the scientific study of history could either retreat to the safe and anticeptic, but increasingly questioned, model of positivism or face the postmodern abyss, eschew the gold standards of objectivity and truth, and reduce history to narrative and discourse alone.

4 With the crisis in view, we are able to see the first of the conceptual options for the study of history, historical positivism, which took a certain conceptual model of the natural sciences as its guide. The next, which reacted most radically to the latter, is historical relativism. If the former is too zealous in its quest for certainty, too reliant on a correspondence theory of truth, and too quick to efface the subjectivity of the historian in her quest for certainty, the latter gives up too much, reduces history to narrative and lacks the denotative reference needed to use historical knowledge to advance reforms and solve problems. In short, one poses as science and the other gives in to fiction.

The question for the pragmatist is always the same, what middle has been excluded when the crisis qua dilemma is posed? Hypothesizing the prospect for a conservative and pragmatic philosophy of history demands that we reject the dilemma as false. Our task then is to take the critical moments of one model seriously - we must read Richard Rorty's seductive critique of foundationalism and the correspondence theory of truth charitably. But in order to conserve the value of the social science of history, we need to retreat to classical, not neo, pragmatism, paying special attention to John Dewey's theory of inquiry and the place of historical judgment therein. In the same way that the negative and critical valence of Rorty's work has antecedents and correlatives on the European Continent, Dewey's reconstruction of history qua inquiry has as its ally on the continent Hans Georg Gadamer. Both of these figures, Gadamer explicitly, and Dewey in a parallel context, responded to what Edmund Husserl referred to a "crisis of the sciences" (Husserl 1970 [1937]). Because the natural sciences, influenced by positivism, had so encroached on the social sciences, they were in need of a reconstruction of their method and self-image. Gadamer and Dewey provide us with such a reconstruction.

6 As we will see, those thinkers who might fall under the umbrella of pragmatism diverge from one another on the nature of historical inquiry as much as some of them diverge from those outside the umbrella. But the scholarly game of determining who is inside and who is outside of club pragmatism is not the best way to spend our energy. Thus, one premise in my present inquiry is that pragmatism is a loose constellation of those thinkers sharing a certain attunements and methods of inquiry. As we will see, the mood common among these figures includes those not ordinarily thought of as in the club. But a pragmatic approach to inquiry is guided by the norm of openness; therefore, I ask my audience to read pragmatically, to allow my denotative depiction of pragmatism to speak for itself, and not to be distracted if my umbrella is cast wide enough to include a tradition from the European Continent - phenomenology.

7 Gadamer gives us a philosophy of history which is pragmatic in that it refuses to efface the subjectivity of the historian in terms of her purposes, guiding interests, and conceptual schemes. Yet Gadamer's philosophy of history is conservative because it refuses to let the subjectivity of the historian become the whole of history. It tills and harvests the soil of history in the admission that the field of potential data cannot be reduced to the engines of its conceptual combine. Thus, there is always a limit to the narratives it tells and always denotative reference points which can restrict its excesses. Much as the blades of the combine's thrasher jam when they encounter a stubborn rock 
in the soil, the historian's ability to spin a tale may be resisted by the text she interprets, according to Gadamer.

8 An understanding of history, reconstructed from John Dewey's Logic: A Theory of Inquiry, is one which views discourse as a function of inquiry, not the other way around (Dewey 1938). Dewey views inquiry as the response to the precarious and problematic character of our biological and cultural environments. Language is an inherited set of tools to help us navigate our inquiries. History qua inquiry views the study of history as a response to a problematic situation and an effort to resolve it. For Dewey, historical inquiries are contextually situated in their theoretical frameworks and limited by their perspectives, but historical propositions do not collapse into mere discourse. Dewey's philosophy of history as inquiry avoids the Rortyan reduction and the postmodern abyss, while conserving the ability of inquiry in the social sciences to resolve problems.

Those following the approach of both Gadamer and Dewey accept an anti-foundational approach to social scientific inquiry, while constraining it with an improved understanding of the relationship between the problems which give rise to our inquiries and the tools which help resolve them. Additionally, their approaches to historical inquiry share a concern for the practical application of the study of history. Both see historical understanding registering as a norm of application. Further, both see that norm guiding the practice of judicial determinations in the court of law, and here we can further see their shared pragmatic sensibility. If we are to conserve the ability of inquiry in the social sciences to resolve problems, we might see how both Dewey and Gadamer give space for historical inquiry to help a judge resolve problems demanding historical understanding. In doing so, Dewey and Gadamer provide a theory of historical inquiry consonant with a conservative and pragmatic judicial theory.

10 If my umbrella of conservative and pragmatic approaches to historical inquiry seems as if it is cast too wide, including a phenomenologist and a naturalist under its shade, I ask my readers to read what follows as hopeful pragmatists, searching for the beneficial similarities between Gadamer and Dewey. They play the same theme, perhaps in different keys. But be sure, whether or not to sponsor Gadamer as a club member is not my concern.

\section{Foundations for Science}

11 Since the time of René Descartes, the aspiration of philosophy was to establish knowledge claims with such certainty as to ground the new science of Galileo and Newton on a firm foundation. René Descartes posited the cogito, a self-same thinking substance, whose security in its reason provided a foundational perspective from which to observe the natural world and articulate its workings scientifically. Immanuel Kant figured that the only way we could make any sense of the world was if all of our judgments about it were accompanied by an "I" which does all the thinking, this the transcendental and synthetic unity of apperception, an ego which necessarily accompanied all of our thoughts. Thus, the cogito or the transcendental ego could be seen as continuous foundations for the possibility of securing scientific claims.

12 But the most mature extension of this pursuit and quest for scientific certainty came with the "Vienna Circle" logical positivists. Inspired by the realists Bertrand Russell and G. E. Moore, these philosophers, including Rudolph Carnap, preoccupied with theoretical 
physics and symbolic logic, concerned themselves primarily with analysis and clarification of meaning with the primary goal of unifying the sciences and providing an account of their operation (West 1989). The enterprise of logical positivism assumed a form of sentential atomism, which correlated isolated sentences with their empirical confirmation by science or with their logical necessity. The truth value of the former, synthetic propositions was judged by the court of empirical observation and the scientific method; the truth value of the latter, analytic statements was judged by the court of formal logic. Sentences regarding ethics, art, or religion, corresponded to what looked like the fictional trash-heap of emotion. The logical positivists reduced experience, (shot through with affectivity and messiness), to sense data. This reduction translated sentences about physical objects into sentences about actual and possible sensations. The positivists attempt to unify the sciences resulted in a diremption of the linguistic, analytic, and theoretical from the empirical, synthetic, and observable (West 1989).

Despite the fact that the positivists' description of the physical and natural sciences was inaccurate, the social sciences, in an attempt to differentiate themselves from philosophy and develop their own "scientific" self-image, transformed the logical positivists' model of science into a reality by their practice of investigating social, cultural, and historical phenomena under the model of positivism (Packer 2011). Making positivism a reality by using its model in historical inquiry participated in what Husserl called the crisis of the sciences. By treating the social spheres they investigated as mathematizable and quantifiable, the social scientist, qua positivist, lost contact with "original human consciousness," and elevated one "attitude toward objects" as "primary and others are ignored and put into abeyance" (Kegley 1978: 187).

We might imagine what "historical positivism" would look like. The historical positivist would state that there is a definite historical fact of the matter that resists revision. The access we have to this fact is more or less an inductive method. The historian culls the documents, which have survived into the present and investigates them with an aim to abstract the general trends which emerge. The fact of the matter becomes what it is by virtue of the number of survivals which speak to it. Borrowing from the positive sciences, the historical positivist avoids lazy induction and seeks out potential documents which might serve as methodological controls on a given question. The positivist tends to use the language of sociology, of necessary and sufficient contributing factors, avoiding the monolithic application of causality in historical relationships except where their claims are most excessive. But the positivist does place a gold standard on quantifiable data and place less emphasis on cryptic survivals which demand fallible interpretation. The elevation of quantifiability to a gold standard runs parallel to the attempt to ignore the fact that such a standard is itself an inherited, contingent historical artifact, and can impose itself on historical data, not allowing other data to speak. History of this sort resists revision insofar as new, emergent attitudes, (the culturally informed subjectivity of the historian) are irrelevant to the way the data speak to the facts. History of this sort can be advanced, but only by the emergence of new data, amenable to judgment by the gold standard, which problematize previous conclusions. Historical positivism advances as science does, with better techniques of uncovering data and with more data to speak for itself. Its normative touchstone is the assurance of its objectivity. Its enemy is subjective excess and reinterpretation devoid of new data. But as we will see its quest for certainty effaces the historian's subjectivity, including the culturally emergent conceptual schemes she uses, from the process of historical inquiry. 
But the quest for certainty and objectivity in the social science of history need not abide by all of the tenets of the aforementioned hypothetical model. The attempt to secure natural science upon a firm foundation, as with Kant and the logical positivists, runs parallel to actual attempts to conduct historical inquiry upon foundational premises. Consider the project of Wilhelm Dilthey, who sought out "a philosophical grounding for historical knowledge" (Gadamer 2004: 215). If Kant had tried to discover how nature could be understood through mathematical constructs, Dilthey, in an attempt to treat experience as an historical science, drew a parallel between the coherence and significance found in the subjective experience of an individual and the coherence of meaning found in the object of historical inquiry. Despite the fact that Dilthey himself knew that the subject of historical inquiry was herself conditioned and contingent, he still sought to establish "knowledge of what was historically conditioned as an achievement of objective science" (Gadamer 2004: 225). Dilthey's attempt to harmonize the human sciences' mode of knowledge with the natural sciences' result-oriented criteria led him to demand the same type of objectivity and method as in the natural sciences, but this was only possible if he "neglected the essential historicity of the human sciences" (Gadamer 2004: 233; Serequeberhan, 1987: 50). What I will show below is that the type of objectivity Dilthey had hoped for is not suitable to the social science of history.

\section{Reading Rorty: The Negative Valence of Pragmatism}

16 The undermining of the project of logical positivism is apiece with the undermining of historical inquiry guided by its foundational premises. A student of Carnap's, W. V. O. Quine, undermined this project of logical positivism from within. In "Two Dogmas of Empiricism," Quine showed that the web of verification about the meaning of observable phenomena was not so thin as to correspond to the truth-value of single sentences (Quine 1951). Instead the web needed to be cast wider to include entire theories and communities of language users. Nor could each synthetic statement improve its likelihood of truth by the occurrence of a specific set of sensory events. In these ways, Quine showed that the verification theory of meaning and the reductionism on which it is founded, atomized human experience to such a degree that it ignored the corporate and communal character of knowledge, and the communal origins of its use (Quine 1951). Further, Quine's critique showed just how theory-laden all observation is because the observer brings with her the language of her community and the conceptual schemes and inherent prejudices built therein.

But the most revolutionary critique of this shortcoming in academic philosophy in the twentieth century was Richard Rorty's Philosophy and the Mirror of Nature. In it, Rorty employs, among other tools, Quine's holism and Dewey's naturalism to topple the presumption that Nature speaks the language of science, calling for an end of philosophy's task of mirroring nature in mental representation and language. Rorty, by reference to Quine, showed that observation was so theory-laden that truth claims about the world by appeal to a world were bound to be circular. As Cornel West described Quine's position, "We cannot isolate 'the world' from theories of the world, then compare these theories of the world with a theory-free world. We cannot compare theories with anything that is not a product of another theory" (West 1989: 197). Rorty, a thoroughgoing anti-realist, thinks there is a world out there, but that it does not speak 
the language which we create in trying to navigate it. Rorty described his rejection of the correspondence theory of truth, (the mirroring of reality in the mind or in language), when he wrote:

The pragmatists conclude that the intuition that truth is correspondence should be extirpated rather than explicated. On this view, the notion of reality as having a "nature" to which it is our duty to correspond is simply one more variant of the notion that the gods can be placated by chanting the right words. The notion that some one among the languages mankind has used to deal with the universe is the one the universe prefers-the one which cuts things at the joints-was a pretty conceit. But by now it has become too shopworn to serve any purpose. (Rorty 1985: 3)

Rorty views language, including narrative and social scientific vocabularies - not as representing and corresponding to an external reality - but as thoroughly instrumental. These vocabularies are tools we use to solve problems and make the world as we hope it will be, but they are historically emergent and thus contingent. In Irony, Contingency and Solidarity, Rorty tells us how the "historicist turn," (his phrase for the contributions of Hegel, Marx, and Darwin), helped the intellectual community get beyond a confrontation between those, like Plato, who thought that private psychology and public justice were internally related, and those like Nietzsche, who thought that conceptions of public justice were only artifices of private wills to power (Rorty 1989). Rorty paints Nietzsche as an anti-Enlightenment thinker, but one who exhibits all of the tendencies of the Enlightenment, such as universalizing some particular human tendency, (for Nietzsche the will to power), as most fundamental, and therefore one who fails to get beyond metaphysics as he had hoped. According to Rorty, historicists showed that any of these formerly universalized tendencies were contingent products of socialization and cultural circumstance (Rorty 1989: viii).

Rorty's work, building on the conclusions he draws in Philosophy and the Mirror of Nature, argues against the project of unifying public and private strivings in theory and for a program sufficiently ironist, historicist, and nominalist (Rorty 1989: xv). The liberal ironist "faces up to the contingency of his or her most central beliefs - someone sufficiently historicist and nominalist to have abandoned the idea that those central beliefs and desires refer back to something beyond the reach of time and chance" (Rorty 1989: xv). The Rortyan ironist understands that her own driving beliefs are historically contingent and that they are merely nominal, not referring or participating in any conceptual reality; however, the ironist strives to achieve those beliefs, whether private, aesthetic self-creations, or calls to public solidarity and mutual recognition, in spite of their nominalism and lack of metaphysical or theological foundation (Rorty: xv).

The lynchpin holding together Rorty's program is the contingency of language. Rorty rejects the "old" idea that any of our chosen "vocabularies," whether poetic or scientific, can tap into or correspond to any metaphysical or noumenal in-itself. We cannot mirror nature and should give up such a quest (Rorty 1989: 4). For Rorty, nature does not speak, only we do, and all metaphysics, even that which invests history into it, as Hegel's did, is really only a description of various radical redescriptions (which Hegel had interpreted as the movement of Spirit through history) (Rorty 1989: 7). According to Rorty, the positivists view their language, and therefore their historical propositions, "as gradually shaping [themselves] around the contours of the physical world," where "Romantic history of culture sees language as gradually bringing Spirit to self-consciousness" (Rorty 
1989: 19). Rorty thinks that philosophy of language, and therefore philosophy of history, blindly evolve according to the needs to the linguistic community.

\section{Historical Relativism}

But Rorty's critique of foundationalism and correspondence theory of truth, in its undermining of attempts to ground the sciences and achieve objectivity in the human sciences, ends up presenting only a polar opposite approach to the philosophy of history - relativism. The proponent of this postmodern view of history sees the inevitable reduction of historical narratives to sheer interests in the present. For Rorty we can write history as adaptation to present circumstances and needs by spinning stories whose vocabulary does not shape itself around the contours of any objective reality, but which adapts blindly to the needs of the historian. For Rorty, history as narrative discourse is just redescriptive novelty at our service.

Rorty's philosophy of language is pragmatic, in that it builds on Dewey's philosophy of language to a certain extent, viewing language as instrumental and evolutionary. However, the question which must be posed is, how does it stand with respect to the relationship between the purpose of historical inquiry and the tool of propositions which function historically? Language is a tool, and a language of scientific mechanism, not metaphorical flight, suits our purposes better when we want to engineer a machine or do biochemistry. However, historical propositions solve problems too. How do the problems stand in relation to the tools which help resolve them? If all linguistic propositions, situated within a given vocabulary, are redescriptions, then from what perspective do we judge which redescriptions better resolve the problem which led to our historical inquiry? That perspective need not be metaphysically foundational; it would be more impoverished to think itself so - which is why we need to read Rorty's antifoundationalism charitably. But historical inquiry should be clear about the genesis of its own scheme of appropriation and the method of its employment. The more these are opaque to the analysis, the worse off history is, not ontologically, but functionally. Historical knowledge is not simply a feature of reflection, and the process of selecting data for historical inquiry cannot be completed in total each time it is exerted. Instead, each historian provides restraint and resistance to all others, as do the texts they interpret. The field of potential data for historical investigation can be resistant to the concepts used to select and interpret it, and the community of inquiry converges on a more functionally correct history by their redescriptions. Their inquiries are contextually situated in their theoretical frameworks and limited by their perspectives, but they cannot reduce their field of research to that framework without collapsing their own historical propositions into mere discourse. Rorty sees inquiry as a linguistic expression of discourse, but the classical pragmatists see this the other way around - discourse is only a part of inquiry, not its entirety (Hickman 2007: 51). ${ }^{1}$

If we examine the sheer interest driving the relativist's use of history, we find those interests embedded in some customary practice, governed by a practical norm concerning the practical outcome of the interest and the articulation of that interest as conceptually understood. Being intellectually honest about the use of history in a thorough, inclusive, coherent way does not only abide by the intellectual norm of formal self-consistency, it abides by the pragmatic norm of bringing theory and practice closer together. Getting history more correct does too. The postmodernist philosopher of 
history can only offer these discursive descriptions and revisions, and these lack the potential to provide platforms of restraint and denotative reference (Hickman 2007: 51). Pragmatism provides these stable platforms while accepting anti-foundationalism.

The answer to the relativist, including Rorty, is that some norm will drive historical inquiry, and the consequence of separating the intellectual norm of inquiry from the embedded norms of praxis is unpragmatic, leading to a greater separation between theory and practice. That is, the intellectual norms of dealing with history pragmatically, including honesty, inclusion, thoroughness, skeptical reserve, and a melioristic faith, are kinds of embedded norms of praxis. Thinking is an activity, and doing this well is governed by norms which are continuous with ethical norms guiding other types of activities. Thomas Grey provides a reminder of this insight: "Thought always comes embodied in practices _ culturally, embedded habits and patterns of expectation, behavior and response" (Grey 1991: 9, 12). The norms governing our habits and patterns of thought do not allow historical inquiry to be reduced to narrative, as Rorty would have it.

I propose that we take the negative and critical valence of Rorty's postmodern view of history seriously without reducing historical inquiry to the subjectivity of the historian or her contingent cultural schemes of appropriation, (and that includes the schemes of the positivists). We can reject the need for a metaphysical foundational perspective and view language as thoroughly instrumental and evolutionary, while not reducing historical inquiry to discursive flight. As we will see, classical pragmatism retains the negative and critical moments of postmodernism, resisting hasty universalism, foundationalism, and naive correspondence theories of truth. But the classical pragmatists want their historical inquiries to do more than just redescribe. Classical pragmatists find that while some concepts, such as "the individual," whose ontological security had been deconstructed by a variety of postmodern critiques, are useful outcomes of situated historical inquiries and can be used as platforms in future inquiries, as long as their use is sensitive to the context of the involved situation of the future inquiry.

\section{Dewey's Theory of Historical Inquiry in the Key of Naturalism}

Dewey embedded his discussion of the nature of historical judgments within his broader examination of the pattern of inquiry. Dewey was working against several mistakes in the philosophy of logic, which treat logic as either merely dependent upon subjective and mentalistic states and processes, as mere copies of antecedent empirical materials, or as originating outside experience from an a priori or transcendental source (Dewey 1938). Dewey identifies logic with methodology, the theory of inquiry, of which the guiding principles and criteria emerge empirically but have rational standing as affairs of relations of means to consequences. This logic is progressive: logical forms read off from sciences no longer respected by the community of inquiry do not provide coherent accounts of existing scientific methods, and as such, demand revision. The subject-matter of logic is determined operationally. It inquires into both the materials of experimental observation and the symbols which direct reflection on those materials. Furthermore, the latter element in the operation of the logic is delineated by reference to the existential conditions and consequences of the former. But logic is naturalistic: Dewey postulates 
that the biological and cultural existential matrices of inquiry are continuous with the matrix in which inquiry is formal, rational, and takes its own symbols and language as its subject matter. Dewey does not dichotomize realms of inquiries; instead they lie on a spectrum from the problematic situations of the live creature, to common sense, to controlled scientific investigation, to inquiry directed at its own methodology. Although logic is naturalistic, it is a social discipline, conditioned by the natural, communal, and linguistic interactions in of those in community with each other. The logical forms are postulates of inquiry made of and for inquiry as formulations of conditions to be tested by further inquiries until they yield warranted assertibility, (Dewey's fallible replacement for truth). They are not the ultimate a priori grounds or transcendental conditions for possible inquiry yielded by intuition or pure reason. Yet logic is autonomous. It is a circular process because, as inquiry into inquiry, it only depends on that which is connected to inquiry and thereby rules out the importation of metaphysical or epistemological presuppositions, (such as the self-same cogito) "shoved under inquiry as its foundation" (LW 12: 28).

Inquiry follows a pattern, and as we will see below, historical inquiry is no exception. The antecedent condition of inquiry is an indeterminate situation, which is permeated and defined by its particular doubts, questions, uncertainties, and discomforts. Once this precarious situation is subjected to inquiry, it is constituted as a problematic situation. This is a step in inquiry as there has been movement from complete indeterminacy to the identification of the constituents and terms of a given situation, pointing to possible solutions. Reasoning ensues as to direct existential operations by an idea in order to terminate in a resolution by rearranging the conditions of indeterminacy toward settlement and unification.

Dewey frequently uses the example of a trial-at-law to depict both the nature of the pattern of inquiry and to explain denotatively the nature of a judgment. The trial is analogous to a problematic situation, which requires resolution. The disagreement and conflict regarding the significance of what happened led to the uncertainty and dispute in the case. Dewey writes, "The judicial settlement is a settlement of an issue because it decides existential conditions in their bearing upon further activities: the essence of the significance of any state of facts" (LW 12: 124). The judgment is the outcome of inquiry patterned above. The rules of the judicial system fix the significance, relevance, and materiality of the facts produced as evidence. But the quality of the situation, civil or criminal for instance, determines those rules to a certain extent. The rules of the system, therefore, are analogous to the conceptual structures of inquiry brought to bear on a problematic situation. The past bears on the process of inquiry by providing the standards and rules applicable to various kinds of cases. Dewey summarizes by stating: "The theoretical ideal sought to guide judicial deliberation is a network of relations and procedures which express the closest possible correspondence between facts and legal meanings that give them their significance" (LW 12: 124). The consequences of the decision are the effects of the disposition of the originally indeterminate case, and the problematic situation is resolved by being directed as future activities. Dewey's view of historical inquiry is more conservative than Rorty's, in that it maintains a continuity between the purpose of the need for inquiry and the resolution to the indeterminacy which gave rise to the inquiry. Dewey answers the more relevant question of what type of historical analysis can contribute to the resolution of a more specific, novel, and indeterminate case. The pragmatic turn in philosophy generally evades the attempt to 
achieve exact correspondence with truths antecedent to inquiry - the dream of positivism's quest for certainty - in favor of the project of describing and reflecting on experience in order to generate concepts evaluated by their social consequences. Rorty's view of history is pragmatic in just this sense.

But Dewey, although representative of this turn in philosophy, investigates the grounds upon which some historical judgments are made more credible than others. But this was not an attempt to recreate a map of past events on a one-to-one scale, as the positivist would suggest as an aim. Rather, Dewey sought to understand the nature of historical judgments with regard to "the relation of propositions about an extensive past durational sequence to propositions about the present and future" (LW 12: 231). Thus, the relation among these propositions concerns their credibility, relevance, criterion for selection, and multivalent temporal structure. Historical analysis, like inquiries into contemporary physical situations, demand a search for relevant data, criteria for selection formed as conceptual principles for determining the relevance of the data, and systematic conceptions working to arrange the selected data. When historical analysis observes and sorts the data and confirms it as authentic data, the result is propositions about facts which exist in the present, serving as the material for historical inference and reconstruction. These propositions are relevant only in relation to the problem which demanded their search and evaluation, and as such, they are responses to a problematic situation. The historical analysis evaluates and selects these propositions, and not others, based on the conceptual subject-matter with which it operates. But this conceptual subject-matter is too often opaque to the analysis and works as a tacit presupposition. Perhaps in the quest to avoid mere subjectivity, the historian does not reflect upon the problem which demanded the analysis or the conceptual subject-matter which aids the evaluation and interpretation of the relevant propositions - this, the problem of objectivity in the social sciences Gadamer addresses. Thus, the pursuit of objectivity in historical analysis renders it culturally subjective, and the historical sense is susceptible to Rorty's critique of positivism and foundationalism.

Dewey reminds us that the conceptual material employed in writing history is that of the period in which it is written. The more transparent this is made during the analysis the more likely the historian is to abstract the conceptual schemes which a given culture under historical analysis brings to the selection of relevant data left available to the present historian as artifacts. In this sense, history is of the present and of that which is judged significant by the present cultural milieu. The more pressing concerns of the day, whether economic or political, color and direct the investigations into the past, just as the record of rainfall in an ancient civilization brings to light its importance to their then-present situation. Furthermore, the naïve assumption that history is of the past, and had by direct access to history books, is a logical impossibility since "the past is a past-ofthe-present, and the present is the-past-of-a-future-living present" (LW 12: 237). Past events register as relevant because they evince changes, and those changes can only be made evident from the perspective of a given purpose of an inquiry. History must always be rewritten given these temporal and logical observations. Additionally, cries against revisionist history (as disruptions of the settled facts) are as naïve as the view of history as directly accessible via history books. The clarification of these subtleties, including the observation that the current writing of history becomes relevant data for selection by future historians, renders historical analysis more humble, fallible, and self-transparent. 
And these traits, as we will see, could serve the judge doing legal history in an effort to resolve the problematic case at hand.

Dewey's philosophical reflections on historical methodology, which embed historical analysis into a discussion of logic and inquiry, split the difference between the naiveté of positivism and the excesses of postmodernism and Rortyan relativism at the other extreme. His philosophy of history avoids nominalism and the pitfalls both historical positivism and historical relativism. Concerning the latter, historical knowledge is not simply a feature of reflection, which, with its dialectical and self-undermining structure and genesis, can undermine praxis. Nor can the act of selecting data for historical investigation exhaust the data investigated. The field of potential data for historical investigation is independent of the concepts used to select any given data. While all inquiry is contextually situated in a theoretical framework, conceptual scheme, and perspective, reducing the field of data to the scheme chosen turns the results of inquiry into mere discourse and dialectic. But as Larry Hickman points out, for Dewey, discourse is a phase of inquiry, not the other way around. Dewey resists the "infinitely self-reflexive nexus of literary descriptions" of postmodernist history as "divisive relativism" in favor of "the denotative method," which always returns his deliberations to the "pushes and pulls of existential affairs" (Hickman 2007: 21). Dewey writes:

Intelligent understanding of past history is to some extent a lever for moving the present into a certain kind of future. No historic present is mere redistribution, by means of permutations and combinations, of the elements of the past. Men are engaged neither in mechanical transposition of the conditions they have inherited, nor yet in simply preparing for something to come after. They have their own problems to solve; their own adaptations to make. They face the future, but for the sake of the present, not of the future. In using what has come to them as an inheritance from the past they are compelled to modify it to meet their own needs, and this process creates a new present in which the process will continue. History cannot escape its own process. It will, therefore, always be rewritten. As the new present arises, the past is the past of a different present. Judgment in which emphasis falls upon the historic or temporal phase of redetermination of unsettled situations is thus a culminating evidence that judgment is not a bare enunciation of what already exists but is itself an existential requalification. (LW 12: 238)

In summary, the writing of history is an inquiry responding to a problematic situation, whose resolution is a judgment based upon the facts which present themselves to us in the present. History is of the present and is inferential. In history qua inquiry, we see that all history proceeds from a certain set of present interests, which directs the study. For Dewey, clarifying these interests and their accompanying biases genetically and methodologically makes for good history. Genetically, we need to understand how our social customs and individual habits give rise to the values which direct our inquiry. Methodologically, we need to show how those values give us our conceptual schemes of inquiry and render some facts relevant and amenable to those conceptual schemes (Dewey 1925; Auxier 1990).

\section{Gadamer's Theory of Historical Inquiry in the Key of Phenomenology}

John Dewey is not the only representative figure of this philosophy of history. His philosophy of historical judgment is not merely a product of turning the inquiry crank 
according to the pattern he laid out and applying the crank to historical data. Rather, other philosophers from disparate traditions have arrived at similar, pragmatic conclusions regarding the nature of historical inquiry. What we will see in Gadamer's view of history, building on the tradition of phenomenology, is an explication of the role of prejudice in making historical judgment. Gadamer eludes Rorty's relativism, while admitting the role of subjectivity in historical analysis, but in a mediated, constrained way.

34 The search for a philosophy of historical inquiry which rejects, alongside Rorty, a foundational perspective from which to conduct historical inquiry in a quest for a certainty, brings us to Gadamer, who represents another conservative and pragmatic view of historical inquiry. Gadamer's method emerges from the phenomenological tradition initiated by Edmund Husserl, and continued in phenomenological ontology by Martin Heidegger. The two great movements which grew out of Heidegger's Being and Time were deconstruction and hermeneutics. The former, motivated by Heidegger's call for the destruction of Western metaphysics, gave rise to many figures, such as Foucault and Derrida, but also Rorty. Gadamer, as a branch of this latter tradition of hermeneutics, represents a method constrained by conservative and pragmatic norms of inquiry, which resist the infinite interpretation of the postmodern philosophers either doing deconstruction in literary criticism or, alongside Rorty, merely undermining metanarratives meant to provide history with continuity.

Gadamer's inheritance of Husserl and Heidegger is complex. Husserl gave his philosophical progeny several persisting insights. First, Husserl refocused the inquiry away from the what of givenness to the how of givenness. Too many hypothetical constructions and naturalistic assumptions corrupted the purity of the former mode of investigation, according to Husserl. Husserl's quest to rid logic of its psychologistic tendencies eventually led him to his phenomenological reduction and epoché (Husserl 1913). Here, he could give a description of experience uninhibited by either the natural attitude or any naturalistic concepts. ${ }^{2}$ The importance of this for our purposes is that such rigorous attention to the mode of givenness demanded that explanatory devices emerge from a radically empirical description of the modes of givenness, and this resisted the importation of concepts outside of or antecedent to such contextual and modal descriptions. Here we see the skeptical warning against a failure to abide by this procedure. For Husserl the constant danger, of allowing our aesthetic and moral experience to be reduced to the modes of quantification and efficient causation evoked as naturalistic gold standard, signaled a crisis of the sciences. As a positive contribution to this constant threat, Husserl gave phenomenological description of both the constitution of natural, psychic, and spiritual regions of experience (in Ideals II) (Husserl 1952) and the constitution of the laws of logic and reason in the phenomenological transcendental aesthetic (in Analysis of Active and Passive Synthesis) (Husserl 2001 [1929]). The former asked that concepts constituted in different modes of experience be applied to their appropriate region, preventing the crisis, while the latter gave an experiential origin to the original sense-giving sources grounding and accomplishing scientific knowledge. This latter description was in an effort to illuminate, animate, and integrate the sciences into "the spiritual nexus of humanity" (Husserl 2001: 5).

Pragmatism worked to advance the same effort. Dewey warned against the philosopher's fallacy, of taking the conceptual and abstract products of inquiry and treating them as inhering in the indeterminate experience which gave rise to need for inquiry or as easily 
exportable to disparate contexts of inquiry. These efforts in phenomenology and pragmatism are normative throughout and they warn against the tendencies which Husserl referred to as the crisis.

Husserl characterized our experience of time as a synthesis of retentions and protentions. In retention we carry with us our just-past without actively presenting it to ourselves as in memory. In protention we tacitly anticipate our near-futures by expecting that our experience conforms to that which we have habituated in passive synthesis. Our anticipations of concordance, based on certain retentions, unfold against an indeterminate horizon of possibility. But we appropriate them for our pre-understanding of future experience. Our pre-understanding is the experiential substratum for the understanding which predicates our active characterizations of experience. We can confirm experience as concordant, discordant, fulfilled, or unfulfilled, and these judgments are based on a more primordial pre-understanding of experience. Husserl's expression for the pregivenness of objects of the understanding was vorgegebenheit (Husserl 2001).

Heidegger's extension of the phenomenological method and his demand to combine this with ontology is well-known and documented, but I must give Heidegger some treatment if we are to understand Gadamer's hermeneutics more fully. In Heidegger's early thought, the vor-structure of the understanding comes to fruition, and Gadamer continues it with respect to analysis and interpretation. Heidegger takes Husserl's analysis of time consciousness, drags it through history and experience, and the result is a description of the essential structures of Dasein. For Heidegger, Dasein, or human situatedness - the being for whom Being is a question - engages in the world of entities in a way constantly affected by its past, and this pastness of Dasein registers as attunement to the world, or mood. But Dasein, in order to recover itself from inauthentic modes of engagement, must also investigate the experience of its ownmost possibilities, and possibility registers as an orientation to the future. Thus, Dasein, as understanding, is projective of its Being upon possibilities. To develop itself, Dasein must develop the understanding as interpretation. Interpretation is the "working-out of possibilities projected in understanding" (Heidegger 1962: 149). That which as been encountered as ready-to-hand is understood, then comes to be interpreted. The condition of this possibility is that the object which is to be understood as something must already be accessible to the understanding, so that this as-structure may be made to stand out for us. This access presupposes a preunderstanding at work. The interpretation we seek as Dasein, which is of ourselves, has already been determined in a way of envisagement by an advanced grasping, a foreconception of the understanding (Heidegger 1962). Heidegger's expression for this is related to the verb vorgreiffen ("to anticipate") and to the noun Begriff, ("concept") (Heidegger 1962: 150). Here we can see these terms as connoting a pre-conceptualizing or an anticipation of a conceptualization at work in the interpretive process of the understanding. The operative term at work in Gadamer's hermeneutics, which expresses phenomenological inheritance in terms of the vor-structure of the understanding, is Vorteilung ("prejudice") (Gadamer 2004: 241).

Gadamer's impetus to clarify a conception of interpretation was not far a field from the articulations of the crisis above. He felt that the human sciences, (conceived as the "moral sciences," Geisteswissenschaften, or the humanities) were borrowing the inductive logic from the natural sciences as their sole method. But, much in line with Husserl and Heidegger, this copying of the natural and positive sciences ends in an effacement of 
subjectivity as it attempts the impossible - investigating the object of inquiry from a nowhere perspective. That is, the natural sciences invoked a methodology that cannot incorporate the subject with its conceptual schemes and prejudices into its self-aware task.

Gadamer assumes a self-consciously phenomenological approach in his task of reinvesting the human sciences with an understanding of the human condition as interpretive through and through. This registers as a movement away from the whatness of the study (with its objective emphasis) to an examination of the how of the givenness of the object (with its emphasis on modes of givenness). The question for Gadamer is how meaning is constructed and what constitutes and limits the process of construction. The answer to the latter question for Gadamer is history. History constitutes our interpretative capacity by giving us our cultural practices, habits, customs, and concepts as inheritances. By these we are prejudiced in our interpretive projects. Furthermore, Gadamer inherits Husserl's concept of an horizon, as the ever-shifting temporal and spatial limit of our perspective, and translates it into a cultural and conceptual limit, but one which may be fused with others' horizons in the experience of understanding the Other.

41 Therefore, Gadamer gives, in Truth and Method, both an account of historical interpretation and an example of it. This insures that his contribution does not pose as standing outside of the insights he presents, and avoids assuming a self-undermining posture, an attack to which the postmodernists are susceptible. Gadamer takes phenomenology to be the key to overcoming this problem of objectivity in history (Gadamer 2004). By conceiving of our fundamental and ontological orientation to the world as hermeneutic, Heidegger offered a full-blown structure to the way the understanding works in its capacity as projective towards an indeterminate horizon. By giving interpretation a fundamental role, not a supplemental one, in our conception of understanding, Gadamer reinvests the understanding with subjectivity. And such subjectivity is always already historically, and therefore culturally and conceptually, situated. The historicity of the hermeneutic experience speaks to the limitations of hermeneutical consciousness and the finitude of human experience. As Tsenay Serequerbehan put it: "The hermeneutical consciousness does not start from certainties but from a recognition of its own limitations and an experienced appreciation of its heritage" (Serequeberhan 1987: 53). In overcoming the problem of objectivity in history, Gadamer is overcoming the prejudice against prejudice which emerged during the Enlightenment (Gadamer 2004). The prejudice against prejudice suggested that some selfsame foundation, such as reason, could achieve the quest for certainty in science, including historical inquiry.

In order to reveal the dialogical and interactive structure of interpretation, Gadamer emphasizes the need for application of interpretation, and this I offer as evidence of his pragmatic sensibility. Two of his analogues to this process are that we interpret scripture in our application of it in the activity of preaching, and we interpret laws in our application of them to specific cases. The process of interpretation is interactive with the process of applying interpretation. The two mutually inform each other (Gadamer 2004). This is similar to the pragmatic conception of the relation between theory and practice. The former should not be developed antecedent to the latter, much as Gadamer warns against the formulation of any method over and above that which he is instantiating in his history of hermeneutics. 
By his admission of the inevitability of prejudice, Gadamer discloses that which historical positivists want to efface. By his admission of tension with a common object, Gadamer resists the equation of prejudice and object and refuses to inflate interpretability beyond its necessary and conservative constraints, which means that interpretation cannot be poured into any historical text as if such a text were an inert receptacle. Furthermore, practice and application mutually inform conceptualization and theory. Any practical application of theory and interpretation is constrained by the historical reception of concepts which circumscribe, either positively or negatively, the manner in which we project our understanding onto the common objects of interpretation (Gadamer 2004). Historical inquiry, qua Gadamerian hermeneutics, confronts the crisis of the sciences by way of phenomenology, and helps overcome the problem of objectivity; that is, it refuses to pose as positive science and does not attempt to ground historical science upon any "foundation." However, it does not reduce itself to narrative fiction. Guided by pragmatic and conservative norms, it resists historical relativism.

\section{A Conservative and Pragmatic Judicial Theory}

Both Dewey and Gadamer share a common resistance to historical relativism and its view of history as mere redescritive novelty. Such a point of commonality evinces their conservatism. But both Dewey and Gadamer also share an anti-foundational stance, and both respond to the crisis of the sciences. These similarities evince their pragmatism. Additionally, their approaches to historical inquiry share a concern for the practical application of the study of history. Both see historical understanding registering as a norm of application. Further, both see that norm guiding the practice of judicial determinations in the court of law, and here we can further see their shared pragmatic sensibility. If we are to conserve the ability of inquiry in the social sciences to resolve problems, we might see how both Dewey and Gadamer give space for historical inquiry to help a judge resolve problems demanding historical understanding. In doing so, Dewey and Gadamer provide a theory of historical inquiry consonant with a conservative and pragmatic judicial theory.

As we saw above, Dewey exemplifies the way in which adjudicating a problematic and indeterminate situation or case is a synthesis of several temporal phases of inquiry. As an inferential judgment about present propositions which are operationally historical, the judge existentially re-qualifies the present, which serves as potentially relevant data for future propositions operating on the to-be-historical present. What this means is that cries against judicial activism are philosophically analogous to cries against historical revisionism. Judges or historians proper use the conceptual subject-matter of the present cultural environment in order to make historical judgments using present propositions operating historically to resolve novel problematic situations in a trial-at-court (Dewey 1938).

Similar to Dewey, Gadamer refers to the law in order to exemplify the nature of historical inquiry qua hermeneutics. With respect to legal theory Gadamer writes, "The meaning of a law that emerges in its normative application is fundamentally no different from the meaning reached in understanding a text" (Gadamer 2004: 310). Gadamer claims that "a law does not exist to be understood historically," but to be made concrete "in its legal validity by being interpreted" (Gadamer 2004: 307). In judicial determinations, the judge must embrace the tension between the law as a common historical object and the 
changing circumstances and cases in which it must be understood, and then applied (Gadamer 2004). Similar to Heidegger, but also similar to Dewey, Gadamer emphasizes the situatedness of interpretation - that understanding always occurs within an event of tradition, a "process of handing down" (Gadamer 2004: 308). Further the judge must subordinate herself to the text and interpret its will in light of the temporal distance separating her from it and trying to overcome the "alienation of meaning" which the legal text has undergone (Gadamer 2004: 308). This balance between the inheritance of the past and the need for an attunement to the context of the involved situation demanding judgment speaks to the conservatism and the pragmatism of these thinkers. And as I show below, their understanding of historical inquiry is a condition for the possibility of a conservative and pragmatic judicial theory.

Before completing a brief picture of what a pragmatic and conservative judicial theory would look like, I need to distance it from any colloquial associations these terms might harbor. These pragmatic and conservative norms are methodological. They are not political. Pragmatic does not mean left-wing or favoring judicial activism, and conservative does not mean right-wing or reactionary. When legal theorists label judges as conservative, they often mean that their decisions favor a certain coalition of rightwing political, social, or economic interests. ${ }^{3}$

The conditions for a pragmatic and conservative judicial theory fall along several fault lines. Both reject a purely formal approach to adjudication. The pragmatist sees formalism as an extension of the axiomatic and analytic conceptions of law built on the model of positivism, ${ }^{4}$ one of the two poles avoided by both Dewey and Gadamer. The conservative rejects formalism as well because she elevates customary law above either forward-looking statutory law or judicial decisions arrived at only as deductive conclusions. This priority of law in custom speaks to the inheritance of tradition, a Gadamerian insight, and is also pragmatic, as it announces the origin of law in practice not in theory, a Deweyan insight (Dewey 1940). ${ }^{5}$ Next both pragmatism and conservatism require that sound adjudication demands robust historical inquiry. Norms guiding adjudication should not be imported as a priori abstractions from outside the situation demanding inquiry; nor (qua conservative) should they be read-into the past in a relativist approach to history unconstrained the norms and conceptual schemes of the historian; nor (qua pragmatist) should they be lifted from past precedent without special attention to present conditions. The conservative need for historical inquiry constrains its use, preventing radical reforms which can bring with them conditions worse than the situation which gave rise to their need. The pragmatic need for history can work negatively to show when general principles no longer suit present conditions and are ripe for reconstruction, and this is part of Dewey's and Gadamer's resistance to universalism and foundationalism.

The pragmatism of both Gadamer and Dewey accepts an anti-foundational approach to social scientific inquiry, much as it rejects the presuppositions of positivism. The conservatism of Gadamer and Dewey constrains social scientific inquiry with an improved understanding of the relationship between the problems which give rise to our inquiries and the tools which help resolve them. I argue that Gadamer and Dewey, in the different keys of phenomenology and naturalism, play the same theme. In doing so they accept the negative and critical valence of Rorty's postmodernism and neopragmatism. But they refuse to jump into the postmodern abyss. By providing the excluded middle between historical positivism and historical relativism, they provide the norms which make 
possible a conservative and pragmatic judicial theory. Such a theory resists the model of legal positivism and the model of unconstrained judicial radicalism. The play between these two poles provides a model of adjudication which allows for growth and reform in the law, as responses to the changes in other forms of culture, such as art and science, without reducing the process of adjudication to mere discursive flight. Their conservative and pragmatic philosophy of historical inquiry and the judicial theory it makes possible refuses to pose as science, but in doing so, it does not turn into narrative fiction.

\section{BIBLIOGRAPHY}

AUXIER R., (1990), “Dewey on Religion and History,” Southwest Philosophy Review, 6 (1), January.

BELL J.M., (2011), “The German Translation of Royce's Epistemology,” The Pluralist, 6 (1), Spring, 46-62.

DEWEY J., (1896), “The Concept of the Reflex Arc in Psychology,” Early Works, Volume 5, 1895-1898, Ed. Jo Ann Boydston, Carbondale, Southern Illinois University Press, (1967-75).

DEWEY J., (1905), “The Postulate of Immediate Empiricism,” Middle Works, Vol. 3, Edited by Jo Ann Boydston, Carbondale, Southern Illinois University Press, (1976-83).

DEWEY J., (1938), Logic: The Theory of Inquiry. Later Works, Volume 12, 1938, Edited by Jo Ann Boydston, Carbondale, Southern Illinois University Press, (1981-90).

DEWEY J., (1940), “My Philosophy of Law,” Later Works, Volume 14, Edited by Jo Ann Boydston, Carbondale, Southern Illinois University Press, (1981-90).

DWORKIN R., (1986), Law's Empire, Cambridge, Harvard University Press.

GADAMER H. G., (2004), Truth and Method, London, Continuum.

GREY T. C., (1991), “What Good Is Legal Pragmatism?,” Brint \& Weaver (ed.), Pragmatism in Law and Society, Boulder, Colorado, Westview Press.

HEIDEGGER M., (1962), Being and Time, trans. John Macquarrie \& Edward Robinson, San Francisco, Harper.

HICKMAN L., (2007), Pragmatism as Post-postmodernism Lessons from John Dewey, New York, Fordham University Press.

HUSSERL E., (1970), The Crisis of European Sciences and Transcendental Phenomenology, Evanston, Northwestern University Press.

HUSSERL E., (2001), Analyses Concerning Passive and Active Synthesis: Lectures in Transcendental Logic, trans. Anthony Steinbock, Kluwer Academic Publisher, Dordrecht.

KEGLEY Jacquelyn Ann K., (1973), "Royce and Husserl: Some Parallels and Food for Thought," Transactions of the Charles S. Peirce Society, 14 (3), 184-99.

PACKER M., (2011), The Science of Qualitative Research, Cambridge, University Press. 
PEIRCE C. S., (1958-66), Collected Papers, electronic edition, ed. by C. Hartshorne \& P. Weiss, Harvard University Press, Cambridge.

POSNER R., (2008), How Judges Think, Cambridge, Harvard University Press.

QUINE W. V. O., (1963), “Two Dogmas of Empiricism,” From a Logical Point of View, New York, Harper.

RORTY R., (1985), “Texts and Lumps,” New Literary History, 17 (1), Philosophy of Science and Literary Theory Autumn.

RORTY R., (1989), Irony, Contingency, and Solidarity, Cambridge, Harvard University Press.

SEREQUEBERHAN Tsenay, (1987), “Heidegger and Gadamer: Thinking as 'Meditative' and as 'Effective Historical Consciousness'," Man and World 20, 41-64.

WEST C., (1989), The American Evasion of Philosophy A Genealogy of Pragmatism, Madison, University of Wisconsin Press.

\section{NOTES}

1. Postmodernist and relativist history, in its most excessive incarnations, results only in "expressions of an infinitely self-reflexive nexus of literary descriptions and redescriptions which are tantamount to interminable discursive flights that do not offer the possibility of firm, behavioral, referential perches," as Larry Hickman put it (Hickman 2007: 51). Rorty raises the relativism of infinite interpretability and redescription to an absolute of its own, the same way Nietzsche raised anti-reason to one.

2. That Husserl wrote with naturalism in the background as a tacit or explicit opponent should not prevent the building of any bridges between phenomenology and pragmatism. Dewey was a naturalist, but he worked with a method of non-reductive empiricism, which refused to reduce experience to sensation, as some British empiricists and the positivists did. See John Dewey, "The Concept of the Reflex Arc in Psychology," (Dewey 1896). Further, Dewey offered the postulate that "things - anything and everything - [...] are what they are experienced as" (Dewey 1905). His naturalism was radically empirical, inspired in part by William James, of whom Husserl was another inspired reader. His turn to view things as they are experienced can be described according to the phenomenological catch phrase, "to the things themselves." Dewey, too, was looking at the how of givenness, although never articulating any explicit epoché, as Peirce, a fellow pragmatist, did, in his description of presentness when he wrote: "The first and foremost is that rare faculty, the faculty of seeing what stares one in the face, just as it presents itself, unreplaced by any interpretation, unsophisticated by any allowance for this or for that supposed modifying circumstance. This is the faculty of the artist who sees for example the apparent colors of nature as they appear" (Peirce 1958-66, 5: 1.42). Here, Peirce, the founder of American pragmatism, "brackets" “interpretation" and "modifying circumstances." Such was Dewey's task in his postulate of immediate empiricism (Dewey 1905). For even more insight into the historical connections between pragmatism and phenomenology, see Bell J. M. (2011). Husserl advised a dissertation on Royce by Winthrop Bell, and Husserl was therefore well aware of Royce's pragmatic idealism.

3. These colloquial associations die hard. Ronald Dworkin referred to this tendency when he claimed that popular imagination sorts Supreme Court justices into two camps, "liberal" and "conservative." Dworkin thinks that one criterion for distinguishing these two camps lines up more or less along the lines of right and left wing politics. See Dworkin R., (1986: 358). Richard 
Posner recently made a similar assertion. Justices are considered conservative and liberal according to their politics. See Posner R. (2008: 9).

4. Legal pragmatists, such as Oliver Wendell Holmes Jr., reacted to the formalism and the positivism of the utilitarian approaches to law, offered by John Austin, a student of Jeremy Bentham. Holmes has been offered by several intellectual historians as a founder of American pragmatism. His preparatory essays for the The Common Law (1881) were written around the time he was in conversation with other classical American pragmatists, C. S. Peirce and William James. 5. Dewey maintained this in his essay "My Philosophy of Law" (1940). The principles guiding adjudication need to emerge from customary practice because that is where they must return, and importing them from outside communal practice or the relevant situation decreases the probability that they would ameliorate the legal situation to which they apply.

\section{ABSTRACTS}

In this article I present two theories of historical inquiry, which I characterize as conservative and pragmatic. I argue that these two views of history, John Dewey's and Hans Georg Gadamer's, provide an excluded middle between the extremes of positivism and relativism. They are pragmatic insofar as they accept the anti-foundationalist critique of positivism; they are conservative insofar as they refuse to reduce historical inquiry to mere discourse or narrative. Both focus on the situatedness of historical inquiry, paying special attention to the culturally emergent conceptual schemes and prejudices of the historian, but they constrain historical inquiry by providing an improved understanding of the relationship between the problems which give rise to our inquiries and the tools which help resolve them. Dewey, in the key of naturalism, and Gadamer, in the key of phenomenology, provide conservative and pragmatic philosophies of historical inquiry, which refuse to pose as science, but do not fall into narrative fiction. Additionally, their approaches to historical inquiry share a concern for the practical application of the study of history. In this concern for application, both Dewey and Gadamer provide a theory of historical inquiry consonant with a conservative and pragmatic judicial theory, which rejects both the formalism of legal positivism and the model of unconstrained judicial radicalism.

\section{AUTHOR}

\section{SETH VANNATTA}

Morgan State University

seth.vannatta[at]morgan.edu 